\title{
Political Representation
}

Communities, Ideas and Institutions in Europe (c. 1200-c. 169o)

Edited by

Mario Damen

Jelle Haemers

Alastair J. Mann

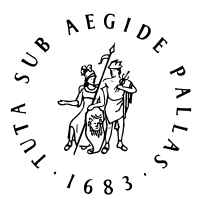

B R I L L

LEIDEN | BOSTON

For use by the Author only | (C) 2018 Koninklijke Brill NV 


\section{Contents}

Acknowledgements IX

List of Illustrations XI

Contributors and Editors XII

An Introduction: Political Representation

Communities, Ideas and Institutions in Europe (c. 120o-c. 169o) 1 Mario Damen, Jelle Haemers and Alastair J. Mann

\section{PART 1}

Top-down or Bottom-up? Princes, Communities and Representation

1 Assemblies of Estates and Parliamentarism in Late Medieval Europe $\quad 19$

Peter Hoppenbrouwers

$2 \quad$ Political Representation and the Fiscal State in Late Medieval and Early Modern Castile 54

María Asenjo-González

3 Forms of Political Representation in Late Medieval Northern Italy Merits and Shortcomings of the City-State Paradigm (14th-early 16 th Century) $\quad 69$

Marco Gentile

4 Representation in Later Medieval and Early Modern Ireland $\quad 85$ Coleman A. Dennehy

$5 \quad$ Speaking in the Name of Collective Action, Claim-making, and the Development of Pre-modern Representative Institutions 106

Tim Neu 


\section{PART 2}

Prelates, Nobles and Patricians: The Composition of the Representative Institutions

$6 \quad$ “The King wishes and commands?" Reassessing Political

Assembly in Scotland, c.1286-1329 125

Michael Penman

7 Officers of State and Representation in the Pre-modern Scottish Parliament 142 Alastair J. Mann

8 The Nobility in the Estates of the Late Medieval Duchy of Brabant $\quad 161$

Mario Damen

$9 \quad$ Representation by Numbers

How Attendance and Experience Helped Holland to Control the Dutch

States General (1626-163o) 182

Ida Nijenhuis

\section{PART 3}

Controlling the State: Ideas and Discourses

10 The Antwerp Clerk Jan van Boendale and the Creation of a Brabantine Ideology 205

Robert Stein

11 Rituals of Unanimity and Balance: Deliberation in 15th- to 16thcentury Hainaut

A Fool's Game? 225

Marie Van Eeckenrode

12 Speech Acts and Political Communication in the Estates General of Valois and Habsburg Burgundy c. 1370-1530

Towards a Shared Political Language 240

Jan Dumolyn and Graeme Small 
13 Parliament, War and the "Public Sphere" in Late Medieval England The Experience of Lancastrian Kent $\quad 267$ David Grummitt

14 Who Has a Say? The Conditions for the Emergence and Maintenance of Political Participation in Europe before $1800 \quad 285$

Wim Blockmans

\section{Conclusion}

Reconsidering Political Representation in Europe, 140o-1700 309 Mario Damen, Jelle Haemers and Alastair J. Mann

Selective Bibliography $\quad 319$

Index $\quad 321$ 


\title{
Conclusion
}

\section{Reconsidering Political Representation in Europe, 1400-170o}

\author{
Mario Damen, Jelle Haemers and Alastair J. Mann
}

This collection of essays was structured as a triptych: we wanted to highlight three themes which we consider essential for the study of political representation in the later Middle Ages and the early modern period. The first panel of our triptych had an institutional framework in which we tried to analyse the balance between a bottom-up and a top-down approach, and wanted to assess the ways in which representative institutions functioned as a platform for political dialogue. In the second panel we focused on the persons in and behind the representative institutions and looked for ways to link the achievements of prosopographical research with changes in political dialogue. In the third panel we directed our attention to the ideological world of representation and tried to discern patterns in which political discourses were triggered by institutional developments.

Two recent books on political representation have initiated reflections and reactions of both approval and disagreement in many of the essays in this volume: States of credit. Size, power, and the development of European polities, published in 2011 by David Stasavage, a professor of politics at New York University; and Parlementer. Assemblées représentatives et échange politique en Europe occidentale à la fin du Moyen Âge, published in 2014 by the Canadian historian Michel Hébert. Apparently, it was only possible to write a synthesis on late medieval political representation in Europe from across the Atlantic Ocean, although the scope and the size of both books (224 and 687 pages respectively) differ substantially. Whereas Hébert's book is source-based and more intended as an overview of representative practices throughout Europe and is especially well informed on the Iberian Peninsula, Stasavage is more hypothesis-driven and focuses on the trilateral relationship between political representation, public credit and state formation, stressing the differences between territorial states and city-states.

Following in Hébert's footsteps, Peter Hoppenbrouwers in his article gives an overview of political representation in some "core areas" of Europe, at the same time questioning the use of terms such as "political representation", "representative institution" and "parliament" by late medieval and early modern historians. Most historians nowadays, however, are cautious about drawing direct lines between our present-day representative institutions and those of the past. Hoppenbrouwers underlines that assemblies of estates, his preferred 
term, can only be considered as such, when the third estate, the delegates of the town, were involved in a structural way. Otherwise it is difficult to distinguish these meetings from those organized by the prince or the monarch within his or her "own" institutional framework. The analysis of the participation of urban representatives in the assemblies should therefore be a major focal point for future historians of the history of representation.

Of course, the "urban element" has already been well studied concerning the Low Countries (see the various essays in this volume) but also in the Iberian Peninsula. María Asenjo-González reveals the complicated relationship between the towns and the monarchy. The procurators in the Cortes of Castile originally defended the interests of the towns vis-à-vis the king. In practice, however, it was difficult for the towns to control their delegates especially when they became vassals of the king, from 1419 onwards. The social profile of the procurators included more and more members of noble lineages, an indication that the separation between the second and third estates was not very clear-cut, much like the situation in the Low Countries.

Tim Neu draws our attention to the Holy Roman Empire, which did not garner many pages in the works of Hébert and Stasavage. Neu challenges Stasavage's comparative approach because in his view it is too narrowly focused on "affordability"; in smaller political units, the frequency of representative assemblies was higher than in larger ones because of relatively low transport and communication costs. ${ }^{1}$ Instead, Neu proposes a comparative framework on the basis of the ideas of Michael Saward. In Saward's view, representation is a dynamic relationship based on performative claim-making, a "basic form of the representative claim". ${ }^{2}$ Neu's essay compares political representation in Hesse and Württemberg using Saward's model and looking at collective agency and practices of representative claim-making. This could be a viable way to go, if we really want to compare political representation on a European level.

Comparisons can reveal similarities and differences in the form and function of assemblies of estates across Europe. Institutions were not "invented" or established from one day to another. They grew out of "representative practices", as described in extenso by both Wim Blockmans and Peter Hoppenbrouwers in this volume. The power relationships between different political actors (princes, aristocrats, clerics and urban elites) were decisive for the outcome of the kind of assemblies of estates. But Blockmans distinguishes other

1 As Stasavage indicates in his first footnote, this was already noted in 1978 by Wim Blockmans in "A Typology of Representative Institutions in Late Medieval Europe", Journal of Medieval History 4 (1989), pp. 189-215.

2 Michael Saward, The Representative Claim (Oxford, 2010), p. 36. 
factors that determine this process of institutionalization: geographical and socio-economic circumstances, the formation of political communities and political conflicts and events. In that sense, it is crucial to bridge the medieval — early modern divide, as Coleman Dennehy does in his essay focusing on Ireland. The special geographical position and the political circumstances on the island, which was predominantly agrarian, determined in fact the development of a relatively weak and docile institution. He shows, however, that the institutional development of Parliament in Ireland was by no means a replica of that in England. Moreover, the Gaelic Irish, the aristocrats, the clergy and the urban elites, were poorly represented in the Irish Parliament.

Marco Gentile in his essay, using Stasavage as a counterpoint, argues that "in late medieval Italy political representation in practice went far beyond the concept of the representative and territorial assembly". Gentile stresses, like Damen in his essay, that alongside the official "horizontal" forms of official political representation, vertical forms of representation existed, in the shape of factions in which the most powerful aristocratic families were the nucleus. Ties of dependence, factions and networks of political actors all influenced the process of decision-making, both inside and outside the formal institutional structures. Uncovering these ties and networks is certainly a road for historians to follow in the future, but this, of course, requires a labour-intensive prosopographical approach.

The second section of this collection has, through case study, steered us between competing interpretations of representation. John Watts' thoughtprovoking "domination of structures" synthesis has been seen as less fundamental to the study of members of parliaments and how they represented, in spite of the traditional understanding of the prominent role of separate estates by Helmut Koenigsberger and others. ${ }^{3}$ There is a need to study political actors who as individuals were influential constituent parts of representative institutions. Prosopography, meanwhile, has been vital, but our contributors have avoided Namierite excesses and collective biography has been explored in the context of key societal events and political shocks which produced changes in representative culture. At the same time, the "bottom-up" views of institutional foundation and representative strength, as argued by the likes of Blickle in his analysis of "communalism" within state building, has been set aside in favour of "interest"; a quality that, as each contribution has shown,

3 John Watts, The Making of Polities: Europe, 1300-1500 (Cambridge, 2009), p. 420; Helmut G. Koenigsberger, "Parliaments and Estates", in The Origins of Modern Freedom in the West, ed. R.W. Davis (Stanford, CA, 1995). 
acted simultaneously at individual and corporate levels. ${ }^{4}$ Michael Penman's essay has confirmed that during a dynastic crisis, and with the backdrop of war and civil war, "interest", as expressed in traditional terms through petitioning by individuals and clerical and commercial groups, continued in juxtaposition with princely priorities. Kingdoms or states on a war footing, territorial states, city-states, or a merging of both as with Scotland, do not neatly fall into definitions of intensive representation on the basis of frequency of meeting as suggested by Stasavage, and the nature of representation cannot be separated from the reason that saw the Estates convened in the first place, in this Scottish case, of course, to obtain affirmation to a new regime and the subsequent succession. Also, as Graves puts it, "frequency was no yardstick of importance". Mario Damen's article shows that the medieval duchy of Brabant better fits Stasavage's model, after Blockmans, of a small-scale geographical unit with frequent "affordable" meetings and intensive representative engagement, yet also that the detailed and regionalized convocation lists reveal a bureaucracy that systematically encouraged participation. ${ }^{6}$ Work needs to be done to measure comparatively such bureaucracies in other theatres. His study of the Brabantine estates in the late fourteenth and early fifteenth centuries, especially the nobility, highlights through attendance data the difficulties of definition when diverse types of nobles existed who, while exhibiting some "representative consciousness", nonetheless were often weakly divided from the third estate in a series of networks that pursued particular interests; the Barbantine Estates were but a "conglomerate of interest groups", surely a universal truism.

Ida Nijenhuis also analyses attendance data, this time of deputies' participation in decisions from the resolutions of the States General of the early seventeenth century, focusing especially on the provinces, their rivalries and the domination of Holland, the largest and most wealthy. She confirms that the procedural and representative sophistication of the States General owed much to the example of the States of Holland but also included a revised

4 Peter Blickle, ed., Resistance, Representation and Community (Oxford, 1997); André Holenstein, "Empowering Interactions: Looking at state building from below", in Empowering Interactions: Political Cultures and the Emergence of the State in Europe, 1300-19oo, ed. Wim Blockmans, Jon Mathieu and André Holenstein (Abingdon, 2016), pp. 1-34. Holenstein describes Blickle's rendering of community as "too homogenous or holistic [and tending to] disregard the hierarchies within communities".

5 David Stasavage, States of Credit: Size, Power and the Development of European Polities (Princeton, 2011), pp. 65-68; Michael A.R. Graves, The Parliaments of Early Modern Europe (Harlow, 2001), p. 108.

6 Blockmans, "Representation (since the thirteenth century)", pp. 53-61; Stasavage, States of Credit, pp. $5^{0-51}$. 
committee-based form of decision-making which, though efficient, created provincial resentment reminiscent of that observed by Brown and Mann over committees of the Scottish Parliament in the late seventeenth century, if not quite the fears of corruption emphasized by Elliot and Metcalf for the committees of Catalonia and Sweden. ${ }^{7}$ Holland and the Dutch Republic represent the archetypal example of Stasavage's "state of credit", where a small geographical scale and a wealthy urbanized merchant group facilitated intensive representation, and thereafter enhanced access to credit. ${ }^{8}$ However, it is notable that in spite of the powerful position of Holland, it still worked for political support from other provinces, electing not to undermine the traditional "superiority" of Guelders, the highest-ranked province, when it came to voting and many procedural matters. The continuing war effort made cooperation more necessary than disputation and fostered a degree of institutional solidarity. We would expect solidarity with the monarch to be a feature of crown-appointed officers of state, although, as Alastair Mann's study of Scottish officers confirms, loyalties and common cause existed on a horizontal basis, to their "class", as well as vertically upwards to the crown. Somewhat like the foundational significance of canon law and church councils to medieval parliaments, as traced by Graves and others, ${ }^{9}$ government bureaucracy in a Scottish parliamentary setting moved increasingly into the hands of secular, honorific nobles and "professional" administrators (often lawyers) and away from the clerical incumbents of the late medieval period. This new breed had in common concern for property, land, inheritance, tax, commercial investments and confessional nuances, as well as the social priorities of husbands, fathers and sons. While it is problematic to see these officers as an estate in their own right, within the committees of the Scottish Parliament they sat in equal numbers to the conventional estates. Within these committees and before the whole house, some even opposed crown policies out of principle and in a manner that confirms that a panoply of "interest" was, as these studies have shown, a "selfish gene" that motivated all members of all parliaments.

Our volume demonstrates that not only the institutional and social perspectives have to be taken into account when historians want to understand the history of political representation more fully. Some years ago, in a piece

7 Keith M. Brown and Alastair J. Mann, "Introduction", in The History of the Scottish Parliament, vol. 1: Parliament and Politics in Scotland, 1567-1707, ed. Brown and Mann (Edinburgh, 2005), pp. 24-33, 40-44; J.H. Elliott, The Revolt of the Catalans, 1598-1640 (Cambridge, 1984), pp. 134-37; Michael F. Metcalf, ed., The Riksdag: A History of the Swedish Parliament (Stockholm, 1987), p. 102.

8 Stasavage, States of Credit, pp. 72, 150-55.

9 Graves, Parliaments of Early Modern Europe, pp. 8-9. 
called "Verfassungsgeschichte als Kulturgeschichte", the German historian Wolfgang Reinhard made a plea for a cultural approach to the history of political thinking, constitutional texts and representative institutions. Followed among others by Barbara Stollberg-Rilinger, historians have since then increased their attention to the ideological and performative aspects of representative institutions. ${ }^{10}$ The essays in the third part of this volume give us an insight into exactly these "cultural practices", and the ideas that underpinned the daily activities of deputies who were present at the meetings of the Estates. The contributors to this part focus on the discourse used by the representatives and the ideological background to their speech and writing. For instance, Robert Stein's essay convincingly shows us that texts were produced to legitimize the opposition of urban deputies at representative meetings against political opponents. The fourteenth-century chronicle Brabantsche Yeesten by Jan van Boendale contains several passages in which the Antwerp clerk justified the motivation of the aldermen of his home town in raising their voice against nobles who at the same time tried to influence the decision-making process in the duchy of Brabant. Ideology and propaganda are therefore intermingled in the chronicle, which was in essence a historical account of the lives and deeds of the Dukes of Brabant. The biased historical narrative showed that princes should take the interests of the subjects in general, and of the governors of the main cities in the duchy in particular, into account when they made decisions. "It is not a game to be prince", in Boendale's words, "because more than anyone else they ought to be concerned about governing the land for the common good" (see the quotation of the Brabantsche Yeesten by Stein). Boendale's ideas were shared by many citizens and influenced several subsequent generations. ${ }^{11}$ In sum, the ideas of chroniclers reporting on the functioning of the Estates, as well as the beliefs and thoughts of the representatives themselves are worth considering by historians because they shed a light on what Reinhard would call "the cultural history of political representation".

Both Stein (on Brabant) and Marie Van Eeckenrode (on Hainaut) demonstrate the importance of the role of clerks in the creation of sources that are used for the study of the history of Estates. Not only Jan van Boendale used his

10 Wolfgang Reinhard, "Verfassungsgeschichte als Kulturgeschichte: historische Grundlagen europäischer politischer Kulturen", Jahrbuch für europäische Geschichte, I (2000), p. 115-31; Barbara Stollberg-Rilinger, "Verfassungsgeschichte als Kulturgeschichte", Zeitschrift der Savigny-Stiftung für Rechtsgeschichte. Germanische Abteilung, 127 (2010), pp. 1-32.

11 Valerie Vrancken, "United in Revolt, Common Discourse: Urban and Noble Perceptions of 'Bad Government' in Fifteenth-Century Brabant, 1420-1421", Journal of Medieval History 43 (2017), pp. 579-99. 
pen to distort and distribute memories about the functioning of the Estates, but also the city clerks in the town of Mons (and elsewhere) have reshaped the history of the Estates when reporting on their meetings. Historians are, of course, well aware of the fact that sources only represent a certain vision of the past, and that the archives at their disposal are the product of many processes, strategies and tactical moves of contemporaries to transmit that vision to future generations. Archives and record-keeping have a social history, and their creation and conservation is influenced by political strategies. ${ }^{12}$ Therefore, many reports of the assemblies of estates try to convince their readers that decisions were taken by unanimity. Counter-arguments against final decisions or disputes dividing meetings are hardly mentioned in these documents. Their political function hinders a clear view of what has exactly been said during meetings because they have to show that the land is governed for the common good of everybody. As a result, reports eclipse the diverging interests of subjects by spreading the message of concord and conviviality. One of the main reasons for the existence of the Estates was to maintain peace in the land. Therefore, mentioning discord and quarrels was not what was to be expected in the documents informing us on the content of meetings. Historians can become frustrated over this, though Van Eeckenrode has outlined that studying the discursive practices of such reports opens an interesting world of political ideas yet to be investigated.

Rhetorical strategies used by deputies in order to show that they wanted to maintain the peace, and more general performative aspects of meetings of representatives, are also studied in this volume. Of course, historians should not overemphasize the central notion of performance, as Peter Burke has argued, ${ }^{13}$ although it is clear that meetings of representatives have a strong performative aspect. It is important not only to study what was said, but also how it was said, where, in which tone, etc. The "act sequence" of such meetings is crucial, to paraphrase the terminology used by Dell Hymes (quoted at length in Small and Dumolyn's essay). The weight of certain allegations or arguments made at meetings depends on the moment it was said, by whom, and in which language. As has also been noted for the presence of craftsmen

12 See, for instance, the overview of the literature available on this topic for the early modern period: Alexandra Walsham, "The Social History of the Archive: Record-Keeping in Early Modern Europe", in The Social History of the Archive: Record-Keeping in Early Modern Europe, ed. Liesbeth Corens, Kate Peters and Alexandra Walsham, Past \& Present Supplement 11 (Oxford, 2016), pp. 9-48.

13 Peter Burke, "Performing History: The Importance of Occasions", Rethinking History 9 (2005), pp. 35-52. 
during meetings of urban councils, ${ }^{14}$ it may perhaps be true that some of the representatives did not have real power to influence decisions taken during meetings with the prince, yet the fact that they were present, or that they may have said something, shows that they constituted part of the body politic of the realm. Uttering claims at meetings (as Tim Neu also shows in this volume) is part of a political process, often ritualized and sequenced, but not meaningless. Without the presence of representatives of subjects, albeit that their political influence may have been minor, assemblies of estates cannot be labelled as being representative. Therefore the rituals, speeches and performances taking place at these meetings are essential to understand their meaning.

The fact that subjects were not passive during meetings underwrites a redefinition of the political that renders claims that subordinate groups were either powerless or lacked political awareness difficult to sustain. Furthermore, David Grummitt's essay demonstrates that common people were well aware of issues that were discussed by representatives of the estates in their meetings with higher powers, though their influence on the agenda and the outcome of such meetings was, of course, generally minimal. However, Grummitt—and many scholars with him ${ }^{15}$ — has shown that historians were wrong when they reduced the political actions of commoners to the violence used during periods of unrest. Pamphleteering, petitioning, speaking and shouting in the streets of the late medieval and early modern city were popular means of discussing politics among commoners. Grummitt shows that issues dealt with at the meetings of representatives were echoed in the streets and taverns of late medieval England. Arguments before representatives were translated into popular discourse with the aim of influencing the minds of many. Presumably the graffiti of citizens and the cries of fellow townsmen and women did not reach all representatives, yet perhaps some of them were aware that the populace was following discussions. Clear evidence of the interaction between representatives and the people in the street will perhaps never be found by historians - too few had the interest to write information on such encounters

14 For instance, for sixteenth-century Lyons: Caroline Fargeix, "Mémoire urbaine et opinions politiques: réflexions méthodologiques à partir des registres consulaires de la ville de Lyon", in La comunidad medieval como esfera publica, ed. Rafael Oliva Herrer, Vincent Challet, Jan Dumolyn and Maria Antonia Carmona Ruiz (Sevilla, 2014), pp. 137-52. A similar argument is made by Albert Rigaudière, "Conclusions autour de certaines manières d'aviser", in Consulter, délibérer, décider. Donner son avis au Moyen Age (France-Espagne, VIIe-XVIe siècle), ed. Martine Charageat and Corinne Leveleux-Teixeira (Toulouse, 2010), pp. $335^{-} 55$.

15 We refer to the essays in Justine Firnhaber-Baker and Dirk Schoenaers (eds.), The Routledge History Handbook of Medieval Revolt (London, 2017). 
on a sheet of paper-but that does not mean that representatives lived totally separately from the people they were supposed to represent. By no means did the assemblies of estates take place within a vacuum. As this volume has shown, representatives were people who were part of a vibrant society that was full of ideas and beliefs on how it should be governed. Therefore their words and deeds are well worth further study in the future.

In conclusion, we can say that an exclusive focus on the relationship between institutional development on the one hand, and finance and credit on the other (as, for instance, in Stasavage's approach) is too narrow. In fact, it may be a truism in historiography but this volume again shows that all institutional history has to take into account social and cultural aspects when studying the history of political representation. ${ }^{16}$ When we know more about the members, the officers, the clients and their networks, and when we know more about their ideas, speeches, procedures and rituals, then we get to understand how political representation really worked. Clearly, some of the conclusions made by the authors in this volume confirm that a common pattern of European political representation existed, although local history, custom, scale and geography mattered. Dynamic economic and political circumstances were unpredictable catalysts acting on a range of idiosyncratic and common factors. Explaining the genesis and the functionality of Estates and parliaments is therefore not an easy task for historians, but this book shows that it is surely worth the effort.

16 This is also the direction taken in the volume Jean-Philippe Genet, Dominique Le Page and Olivier Mattéoni, Consensus et répresentation (Paris, 2017) which appeared when this volume went into the process of editing. 